Témoigner

Getuigen
Témoigner. Entre histoire et mémoire

Revue pluridisciplinaire de la Fondation Auschwitz

$118 \mid 2014$

Au nom des victimes. Dictature et terreur d'État en Argentine, Chili et Uruguay

\title{
David Fennario, Bolsheviki: A Dead Serious Comedy
}

David Fennario, Bolsheviki : une comédie très sérieuse

David Fennario, Bolsheviki: een doodernstige komedie

Paola Irene Galli Mastrodonato

\section{OpenEdition}

\section{Journals}

\section{Electronic version}

URL: http://journals.openedition.org/temoigner/1109

DOI: $10.4000 /$ temoigner. 1109

ISSN: 2506-6390

Publisher:

Éditions du Centre d'études et de documentation Mémoire d'Auschwitz, Éditions Kimé

Printed version

Date of publication: 1 October 2014

Number of pages: 152-155

ISBN: 978-2-84174-674-3

ISSN: 2031-4183

\section{Electronic reference}

Paola Irene Galli Mastrodonato, «David Fennario, Bolsheviki: A Dead Serious Comedy », Témoigner. Entre histoire et mémoire [Online], 118 | 2014, Online since 01 October 2015, connection on 23 October 2020. URL : http://journals.openedition.org/temoigner/1109 ; DOI : https://doi.org/10.4000/ temoigner. 1109 


\section{Bolsheviki: A Dead Serious Comedy}

$\rightarrow$ Paola Irene Gall Mastrodonato, She is the translator of Balconville in Italian (Viterbo: Edizione Sette Città 2005).

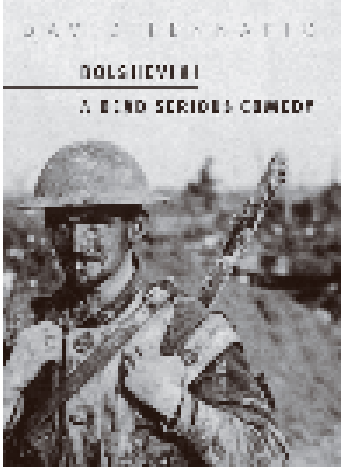

$\triangle$ Bolsheviki: A Dead Serious Comedy, Davi

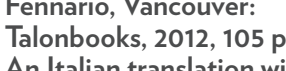
An Italian translation will appear in Teatro canadese: sei drammi (Venezia: Studio
LT2, 2014).

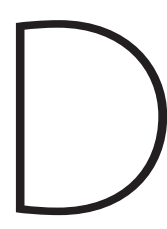

id Fennario, born David Wiper in the working-class district of erdun-Pointe-Saint-Charles at the tip of Montréal island, is consiered one of English Canada's foremost playwrights. His earliest play On the Job (1976), as well as the acclaimed Balconville (1979), the firs bilingual drama in the history of Canadian theatre, have both won the prestigious Chalmers Award, while Joe Beef (1991), where he revisits the origins of his community adopting the Brechtian epic style, has won the Prix Pauline-Julien. In 2003 he won the Montreal Gazette Play of the Year for The Death of René Lévesque, a choral drama reliving through the monologues of five characters the rise and fallof (n) the francophone separatist political leader that also symbolized the first (and last)
experiment in social democracy in North America. periment in social democracy in North America.

In a recent email he has sent me, Fennario defines his theatre as an "antiillusionary style of performance and script", while his message can be summarized as "my celebration of resistance from the ground up". This came admirably into life in Doctor Thomas Neill Cream - Mystery at Mc Gill (1993), where the Dead Founding Fathers from Canada's colonial past are put under trial symbolically by a series of characters who have had no voice in history books: the francophone "Habitants", the Indian servant girl stabbed to death by a powerful Scottish merchant, Camille and Armand whose struggle for independence is thwarted just like their painful love story. Using vaudeville and cabaret musical acts, a sense of impending tragedy ironify ir and suspected of being Jack the Ripper in late Vietorian England. Thus History and Drama unite so that the "audience [can] really think and feel and be moved, hopefully into action against some of the social issues facing us today".

In Fennario's latest piece, Bolsheviki, as well as its sequel, Motherhouse, now in print, it is World War I and specifically the Canadian involvement in it that has undergone close political scrutiny. The play is dedicated to the twenty-five Canadian soldiers who had "met death by firing squad", twenty-three "because they didn't want to get killed" and the other two "for being killers". And the comment is unequivocal "That's a fine distinction considering the fact that these executions took place during " "The the rests from is precisely around this issue, that Bolsheviki debunks our notions of "duty, heroism and warfare" (book jacket description)

When the Performer walks on stage and enters into the character of Jerry Nines, the "skinny-ass, twenty-three-year-old, freelance reporter" sent by a Montréal newspaper to gather interviews of old vets at the 1977 Vimy Ridge World War I Remembrance Day ceremonies, the audience instantly knows that they will be thrown at the center of another hair raising dramatic experience. In Bolsheviki, Fennario confronts us with the uncompromising story of whathappened to veteran Rosie Rollins after he left his smelled of cooked beans, poverty and an uncaring mother, an the Canadian army leaving for the Western front overseas.

The Performer subsequently enters into the character of Rosie (based on real-life WW I veteran Harry "Rosie" Rowbottom, met by the author in the late seventies), happy at first with his shining boots and a brand new rifle dangling from his shoulder, but then suddenly thrown from the safe haven of the training camp in England to the unbearable hell of trench warfare in Flanders:

That's a trench?... looks like ditches like the kind ya dug for a sewer pipe only there was no pipe, just the sewer up to the knees and - move on - MOVE ON - ON - ... With sergeantmajors yelling out your name your name your name your name your number number number and - shells - whee-wump - keep in line keep in line - whee-wump - cartloads of muck in the air - pieces of duckboard - arms and legs and - rifle - and a boot with fucking foot in it - there it goes ... (12-13)

Rosie gets ever deeper into the horror that surrounds him - we see fellow soldier Jimmy Kemson "with a big piece of his stomach blown out all over" (17) and screaming with pain for his "mommy", to whom Rosie shoves "down [the] mouth" the sock taken from his foot to end the agony, or the harvesting into "sandbags" of "pieces of the bodies that got blown all over hell's half acre" (25). At the same time, "posie gradually becomes aware that things have a political overtone. Indeed the troop "sittin ears cold feet cold deep dugout" (23)

A new insight is provided by francophone buddy Rummie Robidou who had to leave Québec after being involved in a strike in a logging quarter. He joined the army as an opponent rather than a convinced conscript fighting for "God, King, and country" (22). Rosie, of Irish descent, speaks the same subaltern language as Rummie - "the hostie de tabarnac de crisse de câlice de Français" (23). The confrontation with the commanding officers, all British like "Captain Talbot Leighton Arnold Rutherford" with the "snooty nose" (30), becomes stringentas the war takes its tollof human lives and wounded coldiers. When Rummie is sent as "volunteer"

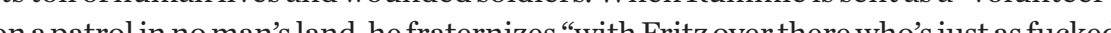
on a pattoln 
the taking of Vimy Ridge by the four Canadian divisions on 12 April 1917, usually described as the funding event of modern Canadian history (see Berton, Pierre, Vimy, Toronto: McClelland \& Stewart, 2010; from the Author's notes), is related to us in a completely un-heroic way through the eyes of Rosie Rollins and his comrades:

Yeah, yeah, Vimy-fucking-Ridge. I was there. "Birth of a Nation" they called it on TV, but I didn't see nobody getting born, just a lot of people dying so we could sit there on top of another shithole of mud with Captain Rutherford still pushing for that DSO or the MC I

Eventually, Rummie refuses to be ordered out on duty and is submitted to a firing squad for "cowardice in the face of the enemy", while handsome Captain Rutherford is hit by a shell just when he was displaying his talent in singing the romantic ballad on "the roses [of] Picardy" (37). Rosie ends up wounded and finds himself lying in bed in a military hospital where he hears about the anti-conscription riots back home in Québec. Suddenly a rising opposition to the mass slaughter in the war is mounting in the ward while from Russia comes the first news of a revolution.

When he finally returns to his neighbourhood in the Pointe, Rosie finds that there is no one left to greet him, "so many people dead, not there no more" (43), and anger together with a new class consciousness turns him into a "regular Bosh-shev-ik[o]":

Yeah - Bosha-viki - that's what they called us when we came back after the war and found ourselves on the streets outta work and started rioting cuz we're pissed off - yeah, sure pissed off after all that bullshit Mr. Face-on-the-Hundred-Dollar-Bill, that prime minister there, that Robert Borden promised us ... Gonna do this for us, gonna do that, make the whole wide world better for all of us by getting rid of the ... Kaiser?... was that the bad guy or was it Kitchener? (7)

We move back from 1919 to the present of the 1977 Remembrance Day, with the Performer shifting to young Jerry Nines. Drunk like Rosie on Bushmills and "cream soda", he stands on a table in the pub where they met, and delivers the final speech:

Comrades and friends ... I'm not here to remember all the guys stupid enough to do what they were told and get themselves killed... I'm here, here to remember the guys who didn't do what they were told and got killed trying to stop you from getting killed ... remember? (45)

Lamentably, the Gazette editor charged to look over Jerry's piece turns it down, claiming it "is not the kind of paper that wants to know nothing from nothing about somebody who thinks peacekeeping means shooting your own officers???" (48). A sorry's interview gets fled “ona self, to move on to "other things" - he is a "soon-to-be-international-media-star" (2).
Meanwhile, in our days, another soldier is getting prepared to go to war

Eeny, meeny, Mickey Maguire

He got sent to Kandahar.

Quick, quick, get a gun,

There goes Mickey on the run.

Eeny meeny, miney moe,

He-came-back-WITHOUT-HIS-TOES! (48)

The play thus ends with a comment on the Canadian involvement in Afghanistan that rejoins what Jerry asked at the beginning:

[...] How many Canadian soldiers been killed in Afghanistan?

Waits for audience response.

Yeah, too many. (2)

Unlike what is usually considered pacifist propaganda, Fennario's heart breaking drama is clearly not about peace, but about war and the Canadian men who fought it. Most of them came from the Anglophone working-class district of Pointe-SaintCharles, and Charles, and were the descendants of the Irsh wh during the Potato Famine of the mid XIX century. They were the "boys that fought at Festubert, Regina Trench, the Somme, Sanctuary Woods, Hill 60, Vimy, Passchendaele" (45), and many, like Rosie Rollins, on their return felt bitterly disillusioned, being often maimed and suffering from what has later been termed post traumatic stress syndrome. Fennario's unsentimental, but at the same time sweetly poetic rendering of life in the trenches during the Great War, is a precise and powerful statement against the mystified and distorted picture of war that we find in history books. Fennario relies both on a rich bibliographical corpus on World War I, and on personal notes retracing his family experience of World War II He drags in Siegfried Sassoon, Wilfred Owen and Charlie Chaplin, while unveiling an obscure Siegfied Sasson, Willo episode that happened in a small village in Wales. On 4 and 5 March 1919, thousands of battle-weary Canadianveterans turned on their officers. 22-year-old David Gillan was killed in the event: another unofficial (until recently) casualty on top of the "more than 66,650 Canadian soldiers [who had] died in the First World War", and the "172,950 [that] were wounded" on a total population of only 8 million in 1918 (53). If the thin line between the just war and a widespread massacre is to be measured quantitatively as well as politically, we must rely on testimonies such as the one delivered masterfully by David Fennario and his Rosie Rollins, and accept our role of not so innocent spectators in a belligerent although democratic world. 